\title{
Pemberitaan Kasus Tindak Upaya Bunuh Diri di Media Siber Tahun 2018 (Studi Kasus Pedoman Peliputan Bunuh Diri oleh Dewan Pers)
}

\author{
Laras Chandra Kancana, Ahmad Junaidi \\ laras.915150204@stu.untar.ac.id,ahmadd@fikom.untar.ac.id \\ Fakultas Ilmu Komunikasi Universitas Tarumanagara
}

\begin{abstract}
The development of cyber media in Indonesia makes a follow-up of the application in the journalistic code of ethics by cyber media journalists to be more vigilant. The coverage montage were also varied, including suicide cases. With it, Indonesian people's knowledge of mental health is threatened by terrorist reporting that carried out in detail and clear description. The Press Council as a special institution that has an authorization and responsibility in Indonesia is also responsible for restricting these characteristics in Indonesia's Press. This research is conducted with mix methods using case study models and content analysis and interviews as its methods. The primary and secondary data will be obtained from interviews, literature studies and observations. The basis theory in this research is theory of the effects of mass communication. Based on the analysis that has been carried out, the researcher found 15 news related to the reporting of follow-up rebellion that had not yet taken the principles of the Journalistic Code of Ethics which could cause behavioral effects such as suicide copycat. The Indonesian Journalists' Participants Council is expected to continue the health of Indonesia's Press practice and keep an eye to the recently released Suicide Reporting Guidelines in the future.
\end{abstract}

Keywords: Suicide reporting guidelines, jounalism principles, cyber media

\begin{abstract}
Abstrak
Perkembangan media siber di Indonesia membuat rawannya tindak praktik penerapan kode etik jurnalistik oleh wartawan media siber. Pemberitaan yang diliput pun beragam, termasuk di dalamnya kasus tindak upaya bunuh diri. Pengetahuan masyarakat Indonesia tentang kesehatan mental terancam oleh pemberitaan wartawan yang terlalu detail dan terbuka. Dewan Pers sebagai lembaga khusus yang memiliki fungsi dan tanggung jawab mengawasi pers Indonesia, turut serta dalam pembatasan pemberitaan bunuh diri di Indonesia. Penelitian ini dilakukan dengan pendekatan gabungan dan menggunakan model studi kasus, metode analisis isi serta wawancara. Adapun sumber data primer dan sekunder penulis dapatkan dari wawancara, studi pustaka dan observasi. Penelitian ini menggunakan teori efek komunikasi massa. Berdasarkan analisis yang telah dilakukan, penulis menemukan lima belas berita terkait pemberitaan tindak upaya bunuh diri yang belum mengikuti asas-asas Kode Etik Jurnalistik yang dapat menimbulkan efek behavioral berupa copycat suicide. Dewan Pers serta wartawan Indonesia diharapkan dapat terus mengawasi kesehatan pers serta menjalankan pedoman pemberitaan terkait tindak upaya bunuh diri.
\end{abstract}

Kata kunci: pedoman pemberitaan tindak upaya bunuh diri, prinsip jurnalisme, media siber 


\section{Pendahuluan}

Fenomena media konvergensi di masa modern ini telah meningkat pesat di masyarakat. Singkatnya, fenomena konvergensi mengubah hubungan dalam produksi dan konsumsi di masyarakat sosial. Media berbasis internet saat ini menggunakan gabungan beragam jenis media yang biasanya ditemukan pada media tradisional seperti televisi, koran, dan radio dengan sifat komputer yang interaktif.

Fenomena konvergensi media ini mengubah praktik jurnalistik sendiri yang pada dasarnya memiliki pengertian beragam. Jurnalistik pada dasarnya merupakan tindakan diseminasi informasi, opini, dan hiburan untuk khalayak yang sistematik dan dapat dipercaya kebenarannya melalui media komunikasi massa modern. Namun semua itu dilakukan tidak dengan sembarang, melainkan menggunakan praktek dan aturan kaidah jurnalistik. Meski melalui media konvergensi, yaitu daring, berita tetap merupakan produk jurnalistik yang dilakukan oleh reporter dan editor serta wajib berpegang teguh pada proses jurnalistik dalam menerjemahkan setiap peristiwa menjadi bentuk berita dengan menggunakan bahasa yang menarik dan memesona. Kecondongan masyarakat dalam memilih media daring pada saat ini menimbulkan kompetisi atau persaingan antar media agar dapat lebih beragam dalam menyajikan konten.

Di Indonesia, pers memiliki undang-undang dan Kode Etik Jurnalistik. Kehadiran kedua peraturan ini merupakan benteng kemerdekaan pers di Indonesia dan dapat menunjukan bahwa pemahaman terhadap dasar-dasarnya bukan hanya saja perlu tetapi juga penting dalam praktik kegiatan jurnalistik.

Sebagai pengawas independen yang terlepas dari pemerintah, Dewan Pers memiliki salah satu fungsi utama yang dituangkan dalam Pasal 15 ayat (2) c yakni menetapkan dan mengawasi pelaksanaan Kode Etik Jurnalistik, selain juga mengawasi pemberitaan yang berkembang di masyarakat.

Kehidupan di masyarakat pun menjadi sorotan penuh bagi pemburu berita, termasuk gencarnya kasus-kasus yang memiliki kaitan dengan psikologis, yaitu bunuh diri. Media massa di Indonesia harus selalu mengacu kepada Kode Etik Jurnalistik pasal 4 dalam memberitakan topik yang berkaitan dengan bunuh diri. Pasal ini berisi tentang wartawan Indonesia yang tidak membuat berita bohong, fitnah, sadis, dan cabul, namun dalam prakteknya, media massa siber masih mendapat banyak teguran dari Dewan Pers terkait peliputan kasus bunuh diri.

Peran seorang jurnalis tidak hanya memulihkan kemerdekaan pers, namun juga menuntut melaksanakan profesionalisme jurnalistik, baik menyangkut aspek jurnalistik maupun aspek pengelolaan pers di masyarakat. Hal ini agar tercipta pencapaian pers yang sehat setelah sebelumnya pers Indonesia berada di bawah naungan pemerintah dan akhirnya disahkan menjadi badan independen. Dewan Pers sebagai badan independen seharusnya dapat memperbaharui kehidupan pers Indonesia sebaik mungkin sesuai dengan UU Pers No. 40 Tahun 1999 yang memuat ketentuan mengenai perusahaan pers untuk menjamin mutu dan performa pers Indonesia.

Penelitian ini ingin melihat bagaimana peliputan kasus bunuh diri di media siber Indonesia sepanjang tahun 2018 dalam mendorong Dewan Pers menyusun Pedoman Peliputan Bunuh Diri. Tujuan penelitian adalah mengetahui bagaimana media siber di tahun 2018 memberitakan kasus bunuh diri terkait kode etik jurnalistik, dan mengetahui bagaimana Dewan Pers menyusun pedoman peliputan kasus bunuh diri di media siber. 
Berdasarkan penjabaran tersebut, penulis berharap ada manfaat akademis maupun praktis yang dapat diambil dari penelitian ini. Di kemudian hari, penelitian ini juga akhirnya dapat menjadi referensi bagi peneliti selanjutnya.

Komunikasi massa adalah produksi dan distribusi yang berlandaskan teknologi lembaga serta arus pesan kontinyu dimana terjadi pendistribusian informasi dari komunikan kepada komunikator di khalayak luas. Di Indonesia, media massa memiliki efek yang besar terhadap kehidupan masyarakat.

Dewasa ini, media siber atau media digital memiliki efek cukup besar terhadap praktek kehidupan sosial masyarakat. Semua orang memiliki gawai dengan sejumlah laman yang terus diakses setiap harinya. Sementara, pemilik media konvensional seperti televisi dan radio pun ikut melakukan konvergensi media ke bentuk digital seperti membuka situs resmi bagi stasiun televisi atau radio.

Jurnalistik siber berkembang karena adanya media siber di masyarakat. Jurnalis Indonesia memiliki etika peliputan yang diberlakukan serta dibuat sendiri oleh wartawan, pedoman ini disebut dengan Kode Etik Jurnalistik. Kode etik jurnalistik memiliki empat asas, yaitu: asas moralitas (nilai-nilai moral yang terkandung didalamnya); asas profesionalitas (membuat berita yang akurat, faktual, jelas sumbernya, dapat membedakan fakta dan opini, tidak membuat berita bohong dan fitnah, menghargai off-record, dll); asas demokratis (wartawan harus bertindak adil, fair, dan berimbang); asas supremasi hukum (wartawan tidak boleh melakukan plagiat, menghormati praduga tidak bersalah, memiliki hak tolak dan tidak menyalahgunakan profesinya).

Komunikasi massa memiliki efek tersendiri ketika khalayak mendapatkan informasi di dalam setiap pesan yang dikonsumsi dan berdampak kepada kehidupan masyarakat sebagai individu sosial, ada tiga efek utama dari pesan di media massa, yaitu efek kognitif, efek afektif dan efek behavioral.

Media massa memiliki efek yang terbagi menjadi empat tipologi yang besar. Pertama, efek media merupakan efek yang direncanakan. Kedua, efek media massa yang tidak direncanakan. Ketiga, efek media terjadi dalam waktu yang cepat. Dan keempat, efek media massa berlangsung dalam waktu yang lama. Keempat tipologi ini menunjukan seberapa besar pengaruh sebuah pesan dalam membingkai opini di masyarakat secara keseluruhan.

Saat ini, wartawan Indonesia masih menggunakan pasal 4 untuk meliput pemberitaan tentang bunuh diri. Dalam Kode Etik Jurnalistik, pasal 4 berbunyi, "Wartawan Indonesia tidak membuat berita bohong, fitnah, sadis, dan cabul."

\section{Metode Penelitian}

Dalam penelitian ini, penulis menggunakan pendekatan jenis gabungan (mix method). Model yang penulis gunakan adalah studi kasus dengan teknik analisis isi dan wawancara. Teknik analisis isi dilakukan dengan pendekatan kuantitatif yaitu menghitung seberapa banyak kasus pemberitaan bunuh diri di media massa serta bagaimana kasus-kasus tersebut mempengaruhi Dewan Pers dalam membuat keputusan merancang pedoman peliputan bunuh diri berdasarkan asas kode etik jurnalistik. Data diperoleh dari wawancara, observasi dan meminta validasi dari narasumber kunci.

Objek penelitian adalah pemberitaan bunuh diri sepanjang tahun 2018. Sementara subjeknya adalah pengawas kesehatan pers Indonesia, Dewan Pers. Penelitian ini merupakan penelitian gabungan. Peneliti menggunakan teknik analisis isi terhadap berita bunuh diri sepanjang 2018 dengan dimensi operasionalisasi 
konsep sesuai dengan prinsip kode etik jurnalistik, yaitu asas moralitas, profesionalitas, dan demokratis.

\section{Hasil Temuan dan Pembahasan}

Berdasarkan penelitian yang penulis lakukan dengan menggunakan teknik analisis isi terhadap pemberitaan bunuh diri sepanjang tahun 2018, terdapat $73.33 \%$ pemberitaan yang berkaitan dengan tindak perilaku serta upaya bunuh diri belum memenuhi asas moralitas, yang menunjukan kurangnya empati wartawan Indonesia terutama di media siber pada himbauan tentang kesehatan mental.

Tabel 1. Berita Belum Memenuhi Asas Moralitas

\begin{tabular}{|ll|c|}
\hline & Frekuensi & 11 Berita \\
\hline & Presentase & $73.33 \%$ \\
\hline
\end{tabular}

Sebanyak $100 \%$ pemberitaan di media siber belum memenuhi asas profesionalitas yakni dengan tidak mencantumkan narasumber dari sisi profesional seperti psikolog. Berita bunuh diri adalah bentuk berita yang berhubungan dengan kesehatan mental, maka wartawan seharusnya meminta kejelasan dari profesional agar mendapat pandangan dari segi sains, bukan hanya fakta di lapangan.

Tabel 2. Berita Belum Memenuhi Asas Profesionalitas

\begin{tabular}{|r|c|}
\hline Frekuensi & 15 Berita \\
\hline Presentase & $100 \%$ \\
\hline
\end{tabular}

Sementara $80 \%$ berita belum memenuhi asas demokratis dengan tidak menulis seruan tentang pencegahan bunuh diri. Penulis menemukan satu berita yang memberikan kontak penyuluhan pentingnya kesehatan mental dan ini yang seharusnya dilakukan oleh jurnalis, termasuk bagaimana ini sudah dimasukkan ke dalam pedoman peliputan bunuh diri yang sudah diterbitkan.

Tabel 3. Berita Belum Memenuhi Asas Demokratis

\begin{tabular}{|c|c|}
\hline \multicolumn{1}{|c|}{ Frekuensi } & 12 \\
\hline Presentase & $80 \%$ \\
\hline
\end{tabular}

Data tersebut menunjukkan kurangnya pengetahuan serta regulasi yang berlaku bagi wartawan untuk memberitakan tindak upaya bunuh diri. Pers internasional telah memiliki pedoman peliputan bunuh diri sejak dahulu sehingga wartawan tidak bisa melakukan interpretasi yang luas terhadap kasus bunuh diri begitu saja. Harus ada regulasi yang berlaku di kode profesi seorang wartawan dan menganggap kasus bunuh diri berbeda dengan kasus kriminalitas yang memiliki unsur kejahatan di dalamnya. 
Seiring dengan tingginya berita yang masih tidak memperhatikan prinsip jurnalistik seperti seharusnya, dan masih luasnya interpretasi terhadap kode jurnalistik pasal 4, dalam tindak serta upaya bunuh diri yang diliput oleh wartawan media siber, penulisan secara detail terutama dalam mengungkap motif dan alat yang digunakan saat melakukan bunuh diri dapat menimbulkan efek behavioral dalam bentuk copycat suicide. Efek ini terjadi karena media secara tidak sengaja telah memperluas pengetahuan bunuh diri di masyarakat melalui efek kognitif, efek ini masuk ke dalam pengetahuan seseorang yang dilansir memiliki kondisi serupa dan memandang bunuh diri sebagai satu-satunya jalan keluar sehingga memicu perasaan seseorang, dalam artian, efek afektif.

Menurut wawancara yang penulis lakukan bersama ketua Dewan Pers, Yosep Adi $\mathrm{P}$, ia menguraikan kebenaran dari efek media massa ini dengan kejadian di Samosir dan Palembang.

“...ada satu keluarga di Samosir bunuh diri dengan cara yang sama cuma bukan dengan pistol karena tidak punya pistol. Jadi istrinya dikasih makan yang isinya racun, anaknya satu tahun dan tiga tahun disuruh minum racun, tapi gak mati, lalu dibacok, dia juga coba tapi cuma luka, kemudian dia ambil silet dia potong baru berhasil. Satu keluarga mati, bagaimana coba kita melihat itu? Media mana yang mau tanggung jawab karena mereka memperluaskan ide bunuh diri?" (Yosep Adi P, Ketua Dewan Pers).

Sebuah keluarga di Samosir, Sumatera Utara ditemukan tewas akibat benda tajam di dalam rumah mereka pada hari Rabu, 24 Oktober 2018. Hanya berselang satu hari, tepatnya pada hari Kamis, 25 Oktober 2018, kasus serupa dimana kepala keluarga melakukan upaya bunuh diri namun lebih rapi dari kasus keluarga di Samosir. Kedua kejadian ini memiliki motif yang hampir serupa, yakni keputusasaan kepala keluarga yang berujung kepada tewasnya seluruh anggota keluarga yaitu ayah, ibu serta anak. Perbedaan dari kedua kasus ini hanya terletak dari alat yang digunakan saat bunuh diri yaitu racun dan pisau dengan pistol yang lebih rapi.

Dengan bahaya efek terhadap kepanikan reaksi kelompok dikemudian hari, Dewan Pers sebagai salah satu pengawas pers Indonesia agar tetap sehat memulai penyusunan pedoman peliputan tindak upaya bunuh diri sejak tahun 2017 dengan melibatkan penggiat pers, jurnalis Indonesia, dan psikolog sebagai profesional dan mengesahkannya tertanda sejak tanggal 22 Maret 2019. Kedepannya, Dewan Pers berharap jurnalis Indonesia akan menerapkan pedoman ini dalam melakukan proyek karya jurnalistik agar tercipta pers Indonesia yang sehat.

"Kita sudah melibatkan beberapa jurnalis senior dan junior dalam FGD saat merancang pedoman peliputan bunuh diri, bicara ke wartawan juga tetap dilakukan untuk menjaga kesesuaian kode etik jurnalistik, verifikasi konfirmasi klarifikasi, yang ada di media sosial itu lakukan seperti informasi, anda tidak boleh sekonyolkonyolnya membuat berita dari bahan media sosial karena bahaya, semuanya sudah diatur dalam pedoman peliputan bunuh diri yang bisa langsung diakses jurnalis." (Yosep Adi P, Ketua Dewan Pers). 


\section{Simpulan}

Seiring dengan tujuan pencapaian fungsi pers Indonesia yang memberikan edukasi dan kontrol sosial, dewan pers merancang pedoman tindak upaya bunuh diri dengan melaksanakan FGD yang dihadiri oleh wartawan Indonesia, pengamat pers, serta psikolog sebagai profesional yang mengenal kasus tersebut secara ilmiah dan berhasil mengesahkannya terhitung pada tanggal 22 Maret 2019.

\section{Ucapan Terima Kasih}

Penelitian ini penulis persembahkan kepada orang tua dan keluarga juga sahabat, Bapak Ahmad Junaidi SS., M.Si., selaku dosen pembimbing yang senantiasa memberikan arahan juga kepada seluruh pihak yang telah membantu dalam melancarkan penelitian ini. Tak lupa ucapan terima kasih yang sebesar-besarnya kepada tim redaksi Jurnal Komunikasi Universitas Tarumanagara yang telah menerima artikel ini untuk dipublikasikan untuk selanjutnya dapat menjadi bahan penelitian dan ajaran.

\section{Daftar Pustaka}

Ambardhi, Kushkrido. 2017. Kualitas Jurnalisme Publik di Media Online: Kasus Indonesia. Yogjakarta: Gadjah Mada University Press.

Ardianto, Komala, dan Karlinah. 2010. Komunikasi Massa (Suatu Pengantar). Bandung: Simbiosa Rekatama Media.

Bungin, Burhan. 2010. Penelitian Kualitatif: Komunikasi, Ekonomi, Kebijakan Publik, dan Ilmu Sosial Lainnya. Jakarta: Prenada Media group.

McQuail, Denis. 1992. Media Performance: Mass Communication and the Public Interest. London: SAGE.

Romli, Asep Syamsul M. 2018. Jurnalistik Online: Panduan Mengelola Media Online. Bandung: Nuansa Cendekia

Romli, Khomsahrial. 2016. Komunikasi Massa. Jakarta: PT Grasindo.

Susanto, E. Haryanto. 2018. Komunikasi Manusia: Teori dan Praktek dalam Penyampaian Gagasan. Yogyakarta: Mitra wacana Media.

Yin, Robert K. 2014. Studi Kasus Desain \& Metode. Jakarta: PT Raja Grafindo. 